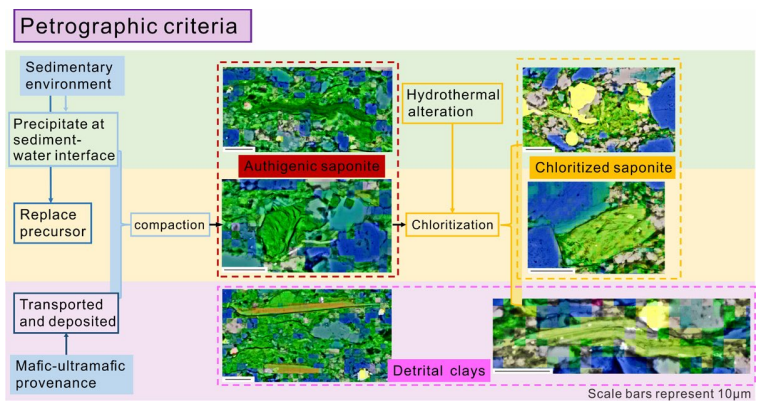

\title{
Authigenic clay mineral evidence for restricted, evaporitic conditions during the emergence of the Ediacaran Doushantuo Biota
}

\author{
SHUJUN HAN ${ }^{1,2}$, STEFAN LÖHR ${ }^{1}$, APRIL ABBOTT ${ }^{1}$,
} ANDRE BALDERMANN ${ }^{3}$ AND BINGSONG YU ${ }^{2}$

\author{
${ }^{1}$ Macquarie University \\ ${ }^{2}$ China University of Geosciences Beijing \\ ${ }^{3}$ Graz University of Technology
}

Presenting Author: shujun.han@students.mq.edu.au

The Ediacaran Period witnessed major environmental change and an expansion of eukaryotic life in the aftermath of the Marinoan glaciation. An expanded sedimentary record including potential earliest metazoan fossils means that the Doushantuo Formation in South China plays an important role in our understanding of Earth System and biospheric evolution during this period. Surprisingly, the depositional setting of the more fossil-rich shallow water Doushantuo deposits remains disputed, with recent work advocating a non-marine setting based on the abundance presence of saponite clay in the lower Dousthantuo of the Yantze Gorges Area [1]. Saponite is a Mg-rich clay that is typically associated with alkaline lake deposits [1], but is not known to form (i.e. in situ precipitation or authigenesis) in open marine sedimentary settings. Alternatively, an input of detrital saponite derived from weathering of an (ultra)mafic hinterland has also been proposed [2]. Here we use a high-resolution scanning electron microscopy-based quantitative mineral mapping approach to show that the saponite is entirely of authigenic origin authigenic origin, dominating the clay content of the $2^{\text {nd }}$ Member of the Doushantuo Fm in the YGA $(\sim 70 \%$ in average), and is petrographically indistinguishable from saponite documented in Cenozoic alkaline lake deposits. Detrital origin clay is minor and chloritization influenced clays from both origins during later burial and kept familiar textures as the precursors. When viewed together with trace element and isotopic constraints, our findings indicate that the lower Doushantuo sediments were deposited in a restricted, evaporitic lagoonal basin, which could contribute to the concentration of $\mathrm{Mg}$ and $\mathrm{Si}$ content and the retention of river runoff-derived essential nutrient elements. This restricted environment could facilitate the precipitation of saponite and also create a favourable environment for early metazoans at a time when open marine settings were still anoxic nutrient deserts.

[1] Bristow TF et.al (2009), Proc Natl Acad Sci U S A 106, 13190-13195.

[2] Huang J et al (2013), Geobiology 11, 3-14. 